\title{
Polymorphisms of fibronectin-1 (rs3796123; rs1968510; rs10202709; rs6725958; and rs35343655) Are Not Associated With Bronchopulmonary Dysplasia in Preterm Infants.
}

Katarzyna Kosik ( $\nabla$ khkosik@gmail.com )

Uniwersytet Medyczny im Karola Marcinkowskiego w Poznaniu https://orcid.org/0000-0001-82043095

Katarzyna Gryczka

Uniwersytet Medyczny im Karola Marcinkowskiego w Poznaniu

Anna Sowińska

Uniwersytet Medyczny im Karola Marcinkowskiego w Poznaniu

Agnieszka Seremak-Mrozikiewicz

Uniwersytet Medyczny im Karola Marcinkowskiego w Poznaniu

Jasmine A. Abu-Amara

Uniwersytet Medyczny im Karola Marcinkowskiego w Poznaniu

Salwan R. Al-Saad

Poznan University of Medical Sciences: Uniwersytet Medyczny im Karola Marcinkowskiego w Poznaniu

Lukasz M. Karbowski

Uniwersytet Medyczny im Karola Marcinkowskiego w Poznaniu

Grażyna Kurzawińska

Uniwersytet Medyczny im Karola Marcinkowskiego w Poznaniu

Marta Szymankiewicz-Bręborowicz

Uniwersytet Medyczny im Karola Marcinkowskiego w Poznaniu

Krzysztof Drews

Uniwersytet Medyczny im Karola Marcinkowskiego w Poznaniu

Dawid Szpecht

Uniwersytet Medyczny im Karola Marcinkowskiego w Poznaniu

\section{Research Article}

Keywords: Fibronectin-1, Polymorphism genes, Bronchopulmonary dysplasia

Posted Date: October 15th, 2021 
DOl: https://doi.org/10.21203/rs.3.rs-968014/v1

License: (c) (1) This work is licensed under a Creative Commons Attribution 4.0 International License. Read Full License

Version of Record: A version of this preprint was published at Molecular and Cellular Biochemistry on March 1st, 2022. See the published version at https://doi.org/10.1007/s11010-022-04397-1. 


\section{Abstract}

\section{Background}

Bronchopulmonary dysplasia (BPD) is a chronic lung disease that mainly affects premature newborns. Many different factors, increasingly genetic, are involved in the pathogenesis of BPD. Fibronectin is a multi-domain glycoprotein present in nearly all vertebrate tissues and organs.

Material and methods

The study included 108 infants born between 24 and 32 weeks of gestation. BPD was diagnosed based on the National Institutes of Health Consensus definition. The 5 FN1 gene polymorphisms assessed in the study were the following: rs3796123; rs1968510; rs10202709; rs6725958; and rs35343655.

Results

BPD developed in $30(38.5 \%)$ out of the 108 preterm infants. Incidence of BPD was higher in infants with lower APGAR scores, low gestational age, and low birthweight. Investigation did not confirm any significant prevelance for BPD development in any genotypes and alleles of FN1.

Conclusion

Further studies should be performed to confirm the role of genetic factors in etiology and pathogenesis of BPD.

\section{Introduction}

Bronchopulmonary dysplasia (BPD) is a severe lung disease of premature neonates born from 22 - 28 weeks of gestational age [1],[2]. As gestational age and birth weight decline, the occurrence of this disease increases and, as such, BPD persists to be the most prevalent complication associated with prematurity [3], [4]. Despite the fact that this condition is usually seen in premature neonates, BPD has been observed in full term infants who require an aggressive form of ventilator therapy for 28 days or longer [5], [6]. Signs and symptoms such as nasal flaring, grunting, tachypnoea and increased respiratory effort can be associated with BPD. Although many causative factors are associated with BPD, pre-term delivery is the leading cause. Other causes also contribute to the pathogenesis of BPD at a lower propensity, which include pre-natal infections, patent ductus arteriosus, mechanical breathing and postnatal infection [7]. Although BPD stems from combined exposures to both pre-and post-natal influences such as those noted above, there is rising concern in the genetic contribution to the development of BPD. The findings of studies in both adults and neonates indicate that after acute lung injury, fibronectin may play a major role in the development of pulmonary fibrosis [8]. Fibronectin is a multi-domain glycoprotein present in nearly all vertebrate tissues and organs [9]. Glycoprotein fibronectin, of high molecular weight, is present in association with basement membranes, as well as in insoluble form in interstitial connective tissue and in soluble form in extracellular fluids such as amniotic, plasma and cerebrospinal fluid [10]. In 
a variety of biological processes, fibronectin plays a crucial role in regards to extracellular matrix adhesion, cell migration, blood coagulation, and wound healing. Fibronectin and other pulmonary cytokines are important players in the successful and orderly repair of wounds; however, the excessive development of these mediators can contribute to an amplification of the normal process of healing with the overall outcome of pulmonary fibrosis [11]. In summarizing the current literature on fibronectin in bronchopulmonary dysplasia, we intend to lay the groundwork for further explanation of the process by which single nucleotide fibronectin polymorphisms may lead to the development of fibrotic disease in BPD.

\section{Material And Methods}

Study Population

The study includes a population of 108 infants born from $22+6$ to $33+6$ weeks of gestation, hospitalized at the Department of Neonatology (III level hospital) in the Clinical Hospital of Gynecology and Obstetrics of Poznan University of Medical Sciences between the years 2014 and 2018. The study did not include neonates born from multiple pregnancies, from pregnancies complicated by death of one of the fetuses, chromosomal abnormalities, TORCH (toxoplasmosis, other, rubella, cytomegalovirus, herpes) complex inflammation, or inherited errors of metabolism and infants without antenatal steroid therapy.

Clinical Features

The following factors that may be associated with the development of BPD were studied: gender, gestational age (GA; weeks), birth weight (BW, grams), mode of delivery (vaginal birth vs cesarean section); APGAR score in 1st and 5th minute, $\mathrm{pH}$ and blood base excess (BE) in cord blood, intrauterine infection, surfactant administration, ventilation mode and its duration. Infants delivered outside the Clinical Hospital of Gynecology and Obstetrics of Poznan University were also analyzed for developing bronchopulmonary dysplasia.

BPD Diagnosis

Bronchopulmonary dysplasia was diagnosed based on the National Institutes of Health Consensus definition. BPD was defined as the need for at least one form of oxygen supplementation either at 28 postnatal days or 36 weeks postmenstrual age (PMA) [12],[13].

Studied Polymorphisms

We studied 5 single nucleotide polymorphisms of fibronectin gene which are the following: rs3796123; rs1968510; rs10202709; rs6725958; and rs35343655 [14],[15]. A sample of blood was taken directly after the delivery and banked. Genomic DNA was extracted from blood leukocytes using QIAamp DNA Blood Mini Kit (QIAGEN Inc; Germany). Genotyping was performed using polymerase chain reaction (PCR) procedures. For detection of FN1 (rs3796123) mutation PCR was amplified with starters: 5'-ACC AAT gCC 
Agg ATT CAg Ag-3', 5'-CCC AAC TTA ggC ATg AgA gC-3' (PCR product 234 bp long) and hydrolyzed with Alul restriction enzyme (Thermo Scientific). The following genotypes were obtained: AA 152, 82 bp; AT 234, 152, $82 \mathrm{bp}$; TT $234 \mathrm{bp}$. For detection of the FN1 (rs1968510) mutation, PCR was amplified with starters: 5'-gTT TgT TgT gTC AgT gTA gTA-3', 5'-TgC ATT AgC gTT ATg gCC ATg-3' (PCR product 784 bp long) and hydrolyzed with Taql restriction enzyme (Thermo Scientific). The following genotypes were obtained: GG 594, 190 bp; GA784, 594,190 bp and AA 784 bp. The FN1 (rs10202709) polymorphism was detected using starters: 5'-CAg TCC CAg ATC ATggAg TCT-3', 5'-gTA CCA TgT TAC TTgTgg AAT AgA g-3'. PCR product (206 bp long) was hydrolyzed with Hindlll restriction enzyme (Thermo Scientific) and found the following genotypes: CC 138, 68 bp; CT 206, 138,68 bp; TT $206 \mathrm{bp}$. For detection of the FN1 (rs6725958) mutation, PCR was amplified with starters: 5'-CTC Agg ACT Tgg ATg gTg TAg A-3', 5'-TCA TTT CCC AAT AAA AgT ACA CTg-3' (PCR product 256 bp long) and hydrolyzed with Haell restriction enzyme (Thermo Scientific). The following genotypes were obtained: CC 171, 85 bp; AC 256, 171, 85 bp and AA 256bp. The FN1 (rs35343655) polymorphism was detected using starters: 5'-ACT gAA gTg CTC ggg ATg AT-3', 5'-CAg gAA CgA AAT gTT ggA Tg-3'. PCR product (236 bp long) was hydrolyzed with Mspl restriction enzyme (Thermo Scientific) and found the following genotypes: GG 139,97 bp; GA 236,139,97 bp; AA 236 bp. Informed consent was obtained from all parents. The study was approved by the Bioethics Committee of Poznan University of Medical Sciences (no. 66/14 and 799/16).

Table 1. Primer sequences, location of the primer pairs, and fragment sizes of fibronectin-1 gene polymorphisms. Fibronectin-1 polymorphisms: rs3796123; rs1968510; rs10202709; rs6725958; rs35343655; Alleles: C, T, G, A. 


\begin{tabular}{|c|c|c|c|c|c|}
\hline Polymorphism & Sequence of primers & Literature & $\begin{array}{l}\text { Product } \\
\text { PCR }\end{array}$ & $\begin{array}{l}\text { Restriction } \\
\text { enzyme }\end{array}$ & $\begin{array}{l}\text { RFLP } \\
\text { products }\end{array}$ \\
\hline \multirow[t]{2}{*}{ rs3796123 } & \multirow[t]{2}{*}{$\begin{array}{l}\text { 5'-ACC AAT gCCAgg ATT } \\
\text { CAg Ag-3' } \\
\text { 5'-CCC AAC TTA }^{\prime} \text { ggCATgAgA gC-3' }\end{array}$} & \multirow[t]{2}{*}{$\begin{array}{l}\text { Untergasser et } \\
\text { al. (2012) }\end{array}$} & \multirow[t]{2}{*}{234 bp } & \multirow[t]{2}{*}{ Alul } & $\begin{array}{l}\text { AA 152, } \\
82 \text { bp } \\
\text { AT 234, } \\
152,82 \text { bp }\end{array}$ \\
\hline & & & & & TT 234 bp \\
\hline \multirow[t]{3}{*}{ rs1968510 } & \multirow{3}{*}{$\begin{array}{l}\text { 5'-gTT } \\
\text { TgTTgTgTCAgTgTA gTA- } \\
3^{\prime} \\
\text { 5'-TgC ATT } \\
\text { AgCgTTATggCCATg-3' }\end{array}$} & \multirow[t]{3}{*}{$\begin{array}{l}\text { Avila et al. } \\
\text { (1999) }\end{array}$} & \multirow[t]{3}{*}{784 bp } & \multirow[t]{3}{*}{ Taql } & $\begin{array}{l}\text { GG 594, } \\
190 \text { bp }\end{array}$ \\
\hline & & & & & $\begin{array}{l}\text { GA784, } \\
594,190 \\
\text { bp }\end{array}$ \\
\hline & & & & & AA 784 bp \\
\hline \multirow[t]{3}{*}{ rs10202709 } & $\begin{array}{l}\text { 5'-CAg TCC CAg ATC } \\
\text { ATggAg TCT-3' }^{\prime}\end{array}$ & \multirow[t]{3}{*}{$\begin{array}{l}\text { Murat et al. } \\
(2015)\end{array}$} & \multirow[t]{3}{*}{206 bp } & \multirow[t]{3}{*}{ HindIII } & $\begin{array}{l}\text { CC 134, } \\
68 \text { bp }\end{array}$ \\
\hline & \multirow[t]{2}{*}{$\begin{array}{l}\text { 5'-gTA CCA TgT TAC } \\
\text { TTgTgg AAT AgA g-3' }\end{array}$} & & & & $\begin{array}{l}\text { CT 206, } \\
138,68 \mathrm{bp}\end{array}$ \\
\hline & & & & & TT 206 bp \\
\hline \multirow[t]{3}{*}{ rs6725958 } & \multirow{3}{*}{$\begin{array}{l}\text { 5'-CTC } \\
\text { AggACTTggATggTgTAg A- } \\
3^{\prime} \\
5^{\prime}-\mathrm{TCA} \text { TTT CCC AAT AAA } \\
\text { AgT ACA CTg-3' }\end{array}$} & \multirow[t]{3}{*}{$\begin{array}{l}\text { Murat et al. } \\
(2015)\end{array}$} & \multirow[t]{3}{*}{256 bp } & \multirow[t]{3}{*}{ Haelll } & AA 256 bp \\
\hline & & & & & $\begin{array}{l}\text { AC 256, } \\
171,85 \mathrm{bp}\end{array}$ \\
\hline & & & & & $\begin{array}{l}\text { CC 171, } \\
85 \text { bp }\end{array}$ \\
\hline \multirow[t]{3}{*}{ rs35343655 } & $\begin{array}{l}5^{\prime}-A C T \text { gAAgTg CTC } \\
\text { gggATg AT-3, }\end{array}$ & \multirow[t]{3}{*}{$\begin{array}{l}\text { Murat et al. } \\
(2015)\end{array}$} & \multirow[t]{3}{*}{236 bp } & \multirow[t]{3}{*}{ Mspl } & AA $236 \mathrm{bp}$ \\
\hline & \multirow{2}{*}{$\begin{array}{l}5^{\prime}-\mathrm{CAg} \text { gAACgA AAT } \\
\text { gTTgA Tg-3' }\end{array}$} & & & & $\begin{array}{l}\text { AC 236, } \\
139,97 \mathrm{bp}\end{array}$ \\
\hline & & & & & $\begin{array}{l}\text { CC } 139 \\
97 \mathrm{bp}\end{array}$ \\
\hline
\end{tabular}

Statistical analysis

Statistical analysis was performed using CytelStudio version 10.0 (CytelStudio Software Corporation, Cambridge, Massachusetts, United States) and Statistica version 10 (Stat Soft, Inc., Tulsa, Oklahoma, United States). The results are presented as a percentage for categorical variables, or median and range for non-normally distributed continuous variables as tested by the Shapiro-Wilk test. A p value of less than 0.05 indicates statistical significance. The Fisher exact probability test, the chi-square test, Fisher Freeman Halton, and Chi-squared test with Yates's correction were all used to evaluate the association between BPD and categorical variables such as gender, GA, BW, type of delivery, birth asphyxia, 
intrauterine infection, Apgar score and delivery outside tertiary referral hospitals. Differences in nonnormally distributed continuous variables were compared by the U Mann-Whitney test.

\section{Results}

Table 2 shows the demographic and clinical characteristics of enrolled infants. In our study population, 30 (38.5\%) infants developed BPD. The incidence of BPD was inversely proportional to multiple criteria, such as: birth weight (incidence was significantly higher in newborns with birth weight less than $1000 \mathrm{~g}$ (76.7\% vs 23.3\%); $p=0,000052)$ ) and lower Apgar score in first (6(1-10) vs 4,5(1-7); $p=0.006)$ and fifth minute of life (7(4-10) vs 7(1-9); $p=0.001)$ had higher incidence of BPD. BPD developed more often in children diagnosed with intrauterine infection $(76.7 \%$ vs $23.3 \% ; p=0.0165)$. Analysis showed higher prevalence of BPD in children ventilated conventionally than in non-invasive mode $(80.0 \%$ vs $20.0 \%$, $p=0,0001)$. Average duration of ventilation of children with BPD was 53,5 days $(8-106, p<0,0001)$. Our investigation did not confirm any significant prevalence for BPD development in any genotypes/alleles of FN1. Genotype and allele distribution of the polymorphisms in infants with or without BPD is presented in Table 3.

Table 2. Demographic and clinical characteristics of enrolled infants. Dell Statistica (data analysis software system), version 10. sofware.dell.com. BPD- bronchopulmonary dysplasia ${ }^{a}$ Chi-square test; ${ }^{b}$ Mann Whitney test; ${ }^{\mathrm{c}}$ Chi-square test with Yate's correction; ${ }^{\mathrm{d}}$ Fisher's exact test 


\begin{tabular}{|c|c|c|c|}
\hline & \multicolumn{2}{|l|}{ BPD } & \multirow[t]{2}{*}{$\mathbf{p}$} \\
\hline & Yes & No & \\
\hline \multicolumn{4}{|l|}{ Gender } \\
\hline Male & $18(60 \%)$ & $44(56.4 \%)$ & \multirow[t]{2}{*}{$0,788^{a}$} \\
\hline Female & $12(40 \%)$ & $33(43.6 \%)$ & \\
\hline Gestational age (week) & $8(26.7 \%)$ & $29(37.2 \%)$ & \multirow[t]{3}{*}{$0,303^{a}$} \\
\hline$<29$ & $22(73.3 \%)$ & $49(62.8 \%)$ & \\
\hline \multicolumn{3}{|l|}{$\geq 29$} & \\
\hline Birth weight (gram) & $7(23.3 \%)$ & $7(9.0 \%)$ & \multirow[t]{4}{*}{$0,000052^{a}$} \\
\hline$<750$ & $16(53.3 \%)$ & $16(20.5 \%)$ & \\
\hline 750-1000 & $7(23.3 \%)$ & $55(70.5 \%)$ & \\
\hline \multicolumn{3}{|l|}{$>1000$} & \\
\hline Apgar score & $4,5(1-7)$ & $6(1-10)$ & \multirow[t]{2}{*}{$0,006^{b}$} \\
\hline 1 st minute & $7(1-9)$ & $7(4-10)$ & \\
\hline \multicolumn{4}{|l|}{ 5th minute } \\
\hline Mode of delivery & $16(53.3 \%)$ & 31 (39.7\%) & \multirow[t]{2}{*}{$0,202^{a}$} \\
\hline Vaginal & $14(46.7 \%)$ & 47 (60.3\%) & \\
\hline \multicolumn{4}{|l|}{ Cesarean section } \\
\hline pH 1 & $7,35(7,00-7,51)$ & $7,31(6,98-7,53)$ & $0,123^{b}$ \\
\hline BE 1 & $-1,4(-11,0-+2,3)$ & $-3,0(-16,9-+10,6)$ & $0,132^{b}$ \\
\hline Intrauterine infection & $23(76.6 \%)$ & $40(51.2 \%)$ & \multirow[t]{2}{*}{$0,0165^{a}$} \\
\hline Yes & $7(23.3 \%)$ & $38(48.8 \%)$ & \\
\hline \multicolumn{4}{|l|}{ No } \\
\hline Inborn & $27(90 \%)$ & $69(88.5 \%)$ & \multirow[t]{2}{*}{$0,909^{c}$} \\
\hline Outborn & $3(10 \%)$ & $9(11.5 \%)$ & \\
\hline Deaths & $0(0 \%)$ & $13(16.7 \%)$ & \multirow[t]{3}{*}{$0,0178^{d}$} \\
\hline Yes & $30(100 \%)$ & $65(83.3 \%)$ & \\
\hline No & & & \\
\hline Surfactant administration & $25(83.3 \%)$ & $30(38.5 \%)$ & $<0,0001^{a}$ \\
\hline
\end{tabular}




\begin{tabular}{|llll|} 
Yes & $5(16.7 \%)$ & $48(61.5 \%)$ & \\
No & & & \\
Ventilation mode & $6(20 \%)$ & $48(61.5 \%)$ & $0,0001^{\text {a }}$ \\
Non-invasive & $24(80 \%)$ & $30(38.5 \%)$ & \\
Donventional & & & \\
Duration of ventilation [days] & $53,5(8-106)$ & $9(1-60)$ & $<0,0001^{\text {b }}$ \\
\hline
\end{tabular}

Table 3. Genotype and allele distribution of infants with or without BPD. Results are expressed as absolute number of patients (percentage). The odds ratio (OR) and $95 \%$ confidence intervals $(95 \% \mathrm{Cl})$ are expressed as the following. AA denotes homozygosity for the A-encoded FN1 rs3796123 (Alul) polymorphism variant; TT homozygosity for the T-encoded FN1 rs3796123 (Alul)T polymorphism variant; AT heterozygosity for FN1 rs3796123 (Alul) polymorphism. GG denotes homozygosity for the G-encoded FN1 rs1968510 (Taql) polymorphism variant; AA homozygosity for the A-encoded FN1 rs1968510 (Taql) A polymorphism variant; GA heterozygosity for FN1 rs1968510 (Taql) polymorphism. CC denotes homozygosity for the C-encoded FN1 rs10202709 (HindIII) polymorphism variant; TT homozygosity for the T-encoded FN1 rs10202709 (HindIII) T polymorphism variant; CT heterozygosity for FN1 rs10202709 (HindIII) polymorphism. CC denotes homozygosity for the C-encoded FN1 rs6725958 (HaellI) polymorphism variant; AA homozygosity for the A-encoded FN1 rs6725958 (HaellI) A polymorphism variant; CA heterozygosity for FN1 rs6725958 (HaellI). AA denotes homozygosity for the A-encoded FN1 rs35343655 (Mspl) polymorphism variant; GG homozygosity for the G-encoded FN1 rs35343655 (Mspl) polymorphism variant; AG heterozygosity for FN1 rs35343655 (Mspl) Cytel Studio version 11.1.0 (January 05, 2016). FN1- fibronectin-1, BPD - bronchopulmonary dysplasia. 


\begin{tabular}{|c|c|c|c|c|c|}
\hline \multicolumn{2}{|l|}{ Polymorphism } & \multirow{2}{*}{$\begin{array}{l}\text { Yes } \\
17\end{array}$} & \multirow{2}{*}{$\begin{array}{l}\text { No } \\
42\end{array}$} & \multirow{2}{*}{$\begin{array}{l}\mathbf{P} \\
\text { value } \\
0,756\end{array}$} & \multirow{2}{*}{$\begin{array}{l}\text { OR } \\
\text { references }\end{array}$} \\
\hline FN1 rs3796123 (Alul) & Genotype & & & & \\
\hline & AA & 1 & 6 & 1 & $0,412(0,008-3,85)$ \\
\hline & TT & 12 & 30 & & $0,988(0,371-2,576)$ \\
\hline & AT & & & & \\
\hline & Allel & 46 & 114 & 0,723 & references \\
\hline & A & 14 & 42 & & $0,826(0,379-1,724)$ \\
\hline & $\mathrm{T}$ & & & & \\
\hline \multirow[t]{7}{*}{ FN1 rs1968510 (Taql) } & Genotype & 25 & 70 & 0,542 & references \\
\hline & GG & 1 & 0 & 0,283 & - \\
\hline & AA & 4 & 8 & & $1,4(0,283-1,724)$ \\
\hline & GA & & & & \\
\hline & Allel & 54 & 148 & 0,319 & references \\
\hline & G & 6 & 8 & & $\begin{array}{l}2,056(0,559- \\
7,087)\end{array}$ \\
\hline & A & & & & \\
\hline \multirow[t]{7}{*}{ FN1 rs10202709 (HindIII) } & Genotype & 22 & 52 & 0,708 & references \\
\hline & $\mathrm{CC}$ & 1 & 6 & 0,914 & $0,394(0,008-3,585)$ \\
\hline & TT & 7 & 20 & & $0,827(0,258-2,425)$ \\
\hline & CT & & & & \\
\hline & Allel & 51 & 124 & 0,47 & references \\
\hline & C & 9 & 32 & & $0,684(0,268-1,602)$ \\
\hline & $\mathrm{T}$ & & & & \\
\hline \multirow[t]{4}{*}{ FN1 rs6725958 (HaellI) } & Genotype & & & & \\
\hline & $\mathrm{CC}$ & 8 & 26 & & references \\
\hline & AA & 7 & 22 & 1 & $1,034(0,271-3,865)$ \\
\hline & $A C$ & 15 & 30 & 0,486 & $\begin{array}{l}1,625(0,538- \\
5,156)\end{array}$ \\
\hline
\end{tabular}




\begin{tabular}{|c|c|c|c|c|c|}
\hline & \multicolumn{5}{|l|}{ Allel } \\
\hline & $\mathrm{C}$ & 31 & 82 & & references \\
\hline & $A$ & 37 & 74 & 0,415 & $\begin{array}{l}1,323(0,718- \\
2,442)\end{array}$ \\
\hline \multirow[t]{7}{*}{ FN1 rs35343655 (Mspl) } & Genotype & 6 & 2 & 1 & references \\
\hline & AA & 46 & 20 & 1 & $0,767(0,07-4,803)$ \\
\hline & GG & 26 & 8 & & $\begin{array}{l}1,083(0,089- \\
7,826)\end{array}$ \\
\hline & GA & & & & \\
\hline & Allel & 38 & 12 & \multirow[t]{2}{*}{0,625} & \multirow{3}{*}{$\begin{array}{l}\text { references } \\
0,776(0,339-1,680)\end{array}$} \\
\hline & $A$ & \multirow[t]{2}{*}{118} & \multirow[t]{2}{*}{48} & & \\
\hline & $G$ & & & & \\
\hline
\end{tabular}

\section{Discussion}

Preterm birth has been associated with an increased risk of both early and late severe clinical difficulties. An increased risk in complications is observed in extremely preterm ( $<28$ weeks of gestational age) and very preterm infants (28-31 weeks of gestational age) With the addition of chronic neurological problems, chronic respiratory problems due to bronchopulmonary dysplasia (BPD) are the most common long-term complications of prematurity [16], [4]. BPD is the result of a multimodal process leading to a severe, lifelong disease. BPD contributes significantly to morbidity and mortality in neonatal intensive care units [17]. The results from a plethora of studies in neonatal care suggest that fibronectin may play a key role in the development of pulmonary fibrosis following acute lung injury [8]. Fibronectin (FN-1) is a large glycoprotein dimer, consisting of two subunits. FN-1 has been observed to change modalities based on its surrounding environment. FN-1 has been reported to hold a soluble form in plasma and an insoluble form when associated with the extracellular matrix, where FN-1 binds to tissues such as collagen. Fibronectin-1 is important for alveolarization and the structural homeostasis of the alveoli [18]. Sinkin and colleagues examined the distribution of pulmonary FN by in situ hybridization (for mRNA) and immunohistochemistry (for protein) in neonatal autopsy lung specimens, comparing lungs with BPD to those without. FN mRNA were detected in vascular endothelium, macrophages, fibroblasts, vascular, airway smooth muscle, chondrocytes and pulmonary parenchyma in children with and without bronchopulmonary dysplasia, but not in epithelial cells. Fibronectin levels were the most increased in early acute BPD, whilst in stabile BPD observed levels were significantly lower [19]. Several studies have documented an increased expression of FN-1 in clinical BPD, including in plasma, endotracheal aspirates, 
BAL fluid and lung tissue. [20]. The excessive production of FN-1 may result in excess and increased propensity of the healing process. The potential role of fibronectin as a possible marker was described by Watts and colleagues [8]. Further investigation by Jeffrey and others indicated that tracheal lavage fibronectin/albumin ratio from patients with BPD was elevated from 3rd week of life [17]. Additional examination of BPD and FN-1 by Zhang and others suggested that decreased miR-206 expression in clinical and experimental BPD may be responsible for the underlying factor of increasing levels of FN-1 noted in the lungs of BPD patients; since FN-1 has been associated to be a target of miR-206. The findings describe a decrease in miR-206 level, whereas FN-1 levels were increased in lungs from hyperoxia-exposed mouse pups [21]. Undoubtedly this idea requires further investigation and experimental demonstration. MicroRNAs are 21-25 nt long non-coding RNAs that are involved in various biological processes such as lung development [22]. Direct analysis showed that miR-206 inhibits the expression of FN-1 by directly interacting with the 3'-UTR of FN-1, miR-206 mediated cell invasion and wound healing effects at least in part through the expression of FN-1. Such expression is abundant in injured tissues which have many putative roles in wound repair. FN-1 shows angiogenic properties and a potential to interact with other key regulators of the extracellular matrix proteins, such as TGF- $\beta 1$ and VEGF. FN-1 activation is believed to be induced by inflammation. Kallapur and McAdams provided evidence for the potential of different levels of inflammation affecting BPD severity [23]. The fibronectin gene has been assessed in relation to various disorders [18]. Polymorphisms and mutations in the FN1 gene have a multimodal association and have been shown to play a role in renal glomerulopathy, spondylometaphyseal dysplasia, lung fibrosis in systemic sclerosis, knee osteoarthritis, lung cancers, gastric cancers, breast cancers, and schizophrenia [24], [25], [14], [26], [27], [28], [29], [30], [31]. Considering the relationship of single nucleotide polymorphisms of fibronectin in neonatal diseases, so far only an association between fibronectin-1 SNP and IVH has been described [32]. Although pathogenesis of IVH is heterogeneous, undoubtedly the fragility of germinal matrix microvasculature plays an instrumental role in its pathology [33]. The requirement of blood vessels is inherent in the development of the basal lamina proper composition [34]. The basal membrane consists of fibronectin, laminin, collagen, perlecans and heparan sulfate proteoglycans [35]. In the human fetus and preterm infants when comparing the germinal matrix with that of the cortex, the concentrations of white matter show significantly decreased levels of fibronectin (with simultaneously constant expression of other components of the basal lamina) [36]. Ballabh and colleagues prove that the mentioned leakage contributes to the fragility of GM (germinal matrix) microvasculature and in consequence increases the propensity of intraventricular hemorrhage [33]. Fibronectin mediates numerous interactions, provides anchoring of fibrinogen and fibula, plays a significant role in maintaining integrity of vasculature by partaking in the creation of the matrix and spreading nascent vessels [34]. Structural integrity and maturation of nascent blood vessels are related to the expression of fibronectin [37]. Leakage of this factor in fibronectin null mice has been shown to cause hemorrhage in central nervous system [38]. Raets and colleagues provided evidence for the GM vulnerability to be adversely affected by a reduction in fibronectin levels. Such reduction of fibronectin levels shows further potential for affecting developmental processes and the stability of cellular structure and architecture [36]. There are many studies that show the significant role that genetics plays in the pathogenesis of BPD [32]. A plethora of data reveal that genetic differences are variable between 
different ethnic groups. In Caucasian populations an interconnection between FGFR-4 SNP rs1966265 polymorphism and both - BPD and RDS frequency is observed [39]. In African-American newborns other genetic variations - IL-18RAP rs3771150 and IL-18R1 rs3771171 - are associated with susceptibility for the development of BPD [40]. Genetic rearrangements in Toll-like receptors indicate different odds of BPD - TLR6 (rs5743827) in African Americans, TLR 2 SNPs in non-Hispanic Caucasians and TLR4 (rs11536898) in both study groups [41]. Our investigation did not confirm any significant prevalence for BPD development in any genotypes or alleles of FN1. However, we believe that this study requires a larger research group to ultimately rule out the role of fibronectin mononucleotide polymorphisms in the pathogenesis of BPD.

\section{Declarations}

Funding: This research received no external funding

Institutional Review Board Statement: The study was conducted according to the guidelines of the Declaration of Helsinki, and approved by the Ethics Committee of Poznan University of Medical Sciences (66/14 and 799/16).

Informed Consent Statement: Informed consent was obtained from all subjects involved in the study.

Conflicts of Interest: The authors declare no conflict of interest.

Author contributions K.K., D.S. designed research; K.K., K.G., A.S, D.S., J.A.A, S.R.A., L.M.K., collected and analysed the data, K.K., D.S., J.A.A, A.S, S.R.A., L.M.K., M.S-B., K.D., A.S-M., G.K., performed research; G.K. was responsible for PCR procedure. All authors commented on the manuscript at all grades.

Research Data Policy and Data Availability Statements The datasets generated during and analysed during the current study are available from the corresponding author on reasonable request.

\section{References}

1. Jobe, A.H. Animal models, learning lessons to prevent and treat neonatal chronic lung disease. Front. Med. 2015, 2, 1-13, doi:10.3389/fmed.2015.00049.

2. Martin, J.A.; Osterman, M.J.K. Describing the Increase in Preterm Births in the United States, 20142016 Key findings Data from the National Vital Statistics System. NCHS Data Brief 2018, 312, 1-29.

3. Wadhawan, R.; Vohr, B.R.; Fanaroff, A.A.; Perritt, R.L.; Duara, S.; Stoll, B.J.; Goldberg, R.; Laptook, A.; Poole, K.; Wright, L.L.; et al. Does labor influence neonatal and neurodevelopmental outcomes of extremely-low-birth-weight infants who are born by cesarean delivery? Am. J. Obstet. Gynecol. 2003, 189, 501-506, doi:10.1067/S0002-9378(03)00360-0. 
4. Stoll B.J., Hansen N.I., Bell E.F., et al. Neonatal outcomes of extremely preterm infants from the NICHD Neonatal Research Network. Pediatrics 2010, 126(3):443-456.

5. Charafeddine, Lama, et al. Atypical Chronic Lung Disease Patterns in Neonates. Pediatrics 1999, 103, 759-765.

6. Lavoie, P.M.; Pham, C.; Jang, K.L. Heritability of bronchopulmonary dysplasia, defined according to the consensus statement of the national institutes of health. Pediatrics 2008, 122, 479-485, doi:10.1542/peds.2007-2313.

7. Pasha, A.B.; Chen, X.Q.; Zhou, G.P. Bronchopulmonary dysplasia: Pathogenesis and treatment (review). Exp. Ther. Med. 2018, 16, 4315-4321, doi:10.3892/etm.2018.6780.

8. Watts, C. L., and A.A.F. Fibronectin: Role in Respiratory Distress Syndrome and Bronchopulmonary Dysplasia. Semin. Perinatol. 1992, 16, 162-169.

9. Henderson, B.; Nair, S.; Pallas, J.; Williams, M.A. Fibronectin: A multidomain host adhesin targeted by bacterial fibronectin-binding proteins. FEMS Microbiol. Rev. 2011, 35, 147-200, doi:10.1111/j.15746976.2010.00243.x.

10. Clemmensen I. Fibronectin and its role in connective tissue diseases. Eur J Clin Invest. 1981, 11(3), 145-6.

11. Hynes, R.O. Fibronectins.

12. Fischer, H.S.; Schmölzer, G.M.; Cheung, P.Y.; Bührer, C. Sustained inflations and avoiding mechanical ventilation to prevent death or bronchopulmonary dysplasia: A meta-analysis. Eur. Respir. Rev. 2018, 27, doi:10.1183/16000617.0083-2018.

13. Isayama, T.; Lee, S.K.; Yang, J.; Lee, D.; Daspal, S.; Dunn, M.; Shah, P.S. Revisiting the Definition of Bronchopulmonary Dysplasia. JAMA Pediatr. 2017, 171, 271, doi:10.1001/jamapediatrics.2016.4141.

14. Avila, J.J.; Lympany, P.A.; Pantelidis, P.; Welsh, K.I.; Black, C.M.; Du Bois, R.M. Fibronectin gene polymorphisms associated with fibrosing alveolitis in systemic sclerosis. Am. J. Respir. Cell Mol. Biol. 1999, 20, 106-112, doi:10.1165/ajrcmb.20.1.3232.

15. Murat, M.; Aekeper, A.; Yuan, L.Y.; Alim, T.; Du, G.J.; Abdusamat, A.; Wu, G.W.; Aniwer, Y. Correlation between the development of calcium oxalate stones and polymorphisms in the fibronectin gene in the Uighur population of the Xinjiang region of China. Genet. Mol. Res. 2015, 14, 13728-13734, doi:10.4238/2015.0ctober.28.35.

16. Natarajan, G.; Shankaran, S. Short- and Long-Term Outcomes of Moderate and Late Preterm Infants. Am. J. Perinatol. 2016, 33, 305-17, doi:10.1055/s-0035-1571150. 
17. Thébaud, B.; Goss, K.N.; Laughon, M.; Whitsett, J.A.; Abman, S.H.; Steinhorn, R.H.; Aschner, J.L.; Davis, P.G.; McGrath-Morrow, S.A.; Soll, R.F.; et al. Bronchopulmonary dysplasia. Nat. Rev. Dis. Prim. 2019, 5, doi:10.1038/s41572-019-0127-7.

18. Mao, Y.; Schwarzbauer, J.E. Fibronectin fibrillogenesis, a cell-mediated matrix assembly process. Matrix Biol. 2005, 24, 389-399, doi:10.1016/j.matbio.2005.06.008.

19. Sinkin, R.A.; Roberts, M.; LoMonaco, M.B.; Sanders, R.J.; Metlay, L.A. Fibronectin Expression in Bronchopulmonary Dysplasia. Pediatr. Dev. Pathol. 1998, 1, 494-502, doi:10.1007/s100249900068.

20. Mižíková, l.; Morty, R.E. The Extracellular Matrix in Bronchopulmonary Dysplasia: Target and Source. Front. Med. 2015, 2, doi:10.3389/fmed.2015.00091.

21. Duan, J.; Zhang, X.; Zhang, S.; Hua, S.; Feng, Z. MiR-206 inhibits FN1 expression and proliferation and promotes apoptosis of rat type II alveolar epithelial cells. Exp. Ther. Med. 2017, 13, 3203-3208, doi:10.3892/etm.2017.4430.

22. de Vasconcellos, J.F.; Jackson, W.M.; Dimtchev, A.; Nesti, L.J. A microRNA Signature for Impaired Wound-Healing and Ectopic Bone Formation in Humans. J. Bone Joint Surg. Am. 2020, 102, 1891-1899, doi:10.2106/JBJS.19.00896.

23. Kallapur, S.G.; Pryhuber, G.S. Bronchopulmonary Dysplasia-The Search for Answers Continues. Clin. Perinatol. 2015, 42, xix-xx, doi:10.1016/j.clp.2015.09.001.

24. Onaran, M.; Yilmaz, A.; Şen, I.; Ergun, M.A.; Çamtosun, A.; Küpeli, B.; Menevşe, S.; Bozkirli, I. A HindIII Polymorphism of Fibronectin Gene Is Associated With Nephrolithiasis. Urology 2009, 74, 10041007, doi:10.1016/j.urology.2009.05.010.

25. Lee, C.S.; Fu, H.; Baratang, N.; Rousseau, J.; Kumra, H.; Sutton, V.R.; Niceta, M.; Ciolfi, A.; Yamamoto, G.; Bertola, D.; et al. Mutations in Fibronectin Cause a Subtype of Spondylometaphyseal Dysplasia with "Corner Fractures." Am. J. Hum. Genet. 2017, 101, 815-823, doi:10.1016/j.ajhg.2017.09.019.

26. Yang, H.Y.; Su, S.L.; Peng, Y.J.; Wang, C.C.; Lee, H.S.; Salter, D.M.; Lee, C.H. An intron polymorphism of the fibronectin gene is associated with end-stage knee osteoarthritis in a Han Chinese population: Two independent case - Control studies. BMC Musculoskelet. Disord. 2014, 15, 1-9, doi:10.1186/1471-247415-173.

27. Qin, S.; Zhang, B.; Xiao, G.; Sun, X.; Li, G.; Huang, G.; Gao, X.; Li, X.; Wang, H.; Yang, C.; et al. Fibronectin protects lung cancer cells against docetaxel-induced apoptosis by promoting Src and caspase-8 phosphorylation. Tumor Biol. 2016, 37, 13509-13520, doi:10.1007/s13277-016-5206-8.

28. Siemianowicz, K.; Gminski, J.; Francuz, T.; Syzdol, M.; Polanska, D.; Machalski, M.; Brulinski, K.; Magiera-Molendowska, H. Fibronectin gene polymorphism in patients with lung cancer. Oncol. Rep. 2001, 
29. Sun, Y.; Ye, Y.; Wang, Z.; He, Y.; Li, Y.; Mao, H.; Zhao, C. High expression of fibronectin 1 indicates poor prognosis in gastric cancer. Oncol. Lett. 2020, 19, 93-102, doi:10.3892/ol.2019.11088.

30. Libring, S.; Shinde, A.; Chanda, M.K.; Nuru, M.; George, H.; Saleh, A.M.; Abdullah, A.; Kinzer-Ursem, T.L.; Calve, S.; Wendt, M.K.; et al. The dynamic relationship of breast cancer cells and fibroblasts in fibronectin accumulation at primary and metastatic tumor sites. Cancers (Basel). 2020, 12, doi:10.3390/cancers 12051270 .

31. Nakata, K.; Ujike, H.; Sakai, A.; Takaki, M.; Imamura, T.; Tanaka, Y.; Kuroda, S. Association study between the fibronectin gene and schizophrenia. Am. J. Med. Genet. - Neuropsychiatr. Genet. 2003, 116 B, 41-44, doi:10.1002/ajmg.b.10796.

32. Szpecht, D.; Al-Saad, S.R.; Karbowski, L.M.; Kosik, K.; Kurzawińska, G.; Szymankiewicz, M.; Drews, K.; Seremak-Mrozikiewicz, A. Role of Fibronectin-1 polymorphism genes with the pathogenesis of intraventricular hemorrhage in preterm infants. Child's Nerv. Syst. 2020, 36, 1729-1736, doi:10.1007/s00381-020-04598-3.

33. Ballabh, P. Pathogenesis and Prevention of Intraventricular Hemorrhage. Clin. Perinatol. 2014, 41, 47-67, doi:10.1016/j.clp.2013.09.007.

34. Tilling, T.; Engelbertz, C.; Decker, S.; Korte, D.; Hüwel, S.; Galla, H.J. Expression and adhesive properties of basement membrane proteins in cerebral capillary endothelial cell cultures. Cell Tissue Res. 2002, 310, 19-29, doi:10.1007/s00441-002-0604-1.

35. Hallmann, R.; Horn, N.; Selg, M.; Wendler, O.; Pausch, F.; Sorokin, L.M. Expression and function of laminins in the embryonic and mature vasculature. Physiol. Rev. 2005, 85, 979-1000, doi:10.1152/physrev.00014.2004.

36. Raets, M.M.A.; Dudink, J.; Govaert, P. Neonatal disorders of germinal matrix. J. Matern. Neonatal Med. 2015, 28, 2286-2290, doi:10.3109/14767058.2013.796169.

37. Xu, H.; Hu, F.; Sado, Y.; Ninomiya, Y.; Borza, D.B.; Ungvari, Z.; LaGamma, E.F.; Csiszar, A.; Nedergaard, M.; Ballabh, P. Maturational changes in laminin, fibronectin, collagen IV, and perlecan in germinal matrix, cortex, and white matter and effect of betamethasone. J. Neurosci. Res. 2008, 86, 14821500, doi:10.1002/jnr.21618.

38. Ballabh, P. Intraventricular hemorrhage in premature infants: Mechanism of disease. Pediatr. Res. 2010, 67, 1-8, doi:10.1203/PDR.0b013e3181c1b176.

39. Rezvani, M.; Wilde, J.; Vitt, P.; Mailaparambil, B.; Grychtol, R.; Krueger, M.; Heinzmann, A. Association of a FGFR-4 gene polymorphism with bronchopulmonary dysplasia and neonatal respiratory distress. Dis. Markers 2013, 35, 633-640, doi:10.1155/2013/932356. 
40. Floros, J.; Londono, D.; Gordon, D.; Silveyra, P.; Diangelo, S.L.; Viscardi, R.M.; Worthen, G.S.; Shenberger, J.; Wang, G.; Lin, Z.; et al. IL-18R1 and IL-18RAP SNPs may be associated with bronchopulmonary dysplasia in African-American infants. Pediatr. Res. 2012, 71, 107-114, doi:10.1038/pr.2011.14.

41. Winters, A.H.; LeVan, T.D.; Vogel, S.N.; Chesko, K.L.; Pollin, T.I.; Viscardi, R.M. Single Nucleotide Polymorphism in Toll-like Receptor 6 Is Associated With a Decreased Risk for Ureaplasma Respiratory Tract Colonization and Bronchopulmonary Dysplasia in Preterm Infants. Pediatr. Infect. Dis. J. 2013, 32, 898-904, doi:10.1097/INF.0b013e31828fc693. 